\title{
Glucocorticoid excess and disturbed hemodynamics in advanced age: the extent to which soy isoflavones may be beneficial
}

\author{
Vladimir Z. Ajdžanović́ ${ }^{1}$ Verica Lj. Milošević ${ }^{1}$ and Ivan B. Spasojević ${ }^{2}$ \\ ${ }^{1}$ Institute for Biological Research "Siniša Stanković", University of Belgrade, Belgrade, Serbia \\ ${ }^{2}$ Institute for Multidisciplinary Research, University of Belgrade, Belgrade, Serbia
}

\begin{abstract}
Advanced age is often accompanied by glucocorticoid excess which contributes to the pathogenesis of the metabolic syndrome associated with some hemodynamic disorders. Impaired central regulation of stress hormones secretion and increased glucocorticoids/adrenal androgens ratio trigger hyperglycemia, elevated blood lipids and visceral fat accumulation, associated with hypertension and increased blood viscosity, all of which represent cardiovascular morbidity factors in this age. Finding the adequate therapeutic solutions is set as an imperative in the treatment of listed symptoms. Biologically active soy isoflavones, exhibiting estrogen- and membrane-receptor agonistic/antagonistic activity, and antioxidative and tyrosine kinase/steroidogenic enzyme inhibiting effects, appear as alternative therapeutics for various ageing-related diseases. It has been shown that soy isoflavones reduce some of the listed risk factors, while affecting the hemodynamic group of cardiovascular parameters directly, as well as indirectly via endocrine perturbations. Soy isoflavones may reverse the glucocorticoids/adrenal androgens ratio, lower serum cholesterol, slow the development of atherosclerotic plaque formation, inhibit platelet aggregation, increase cardiac contractility, but they may have diverse effects on blood viscosity and may increase triglyceride levels. Herein, we present the projection of soy isoflavones-based therapy of glucocorticoid excess and disturbed hemodynamics in advanced age, concluding that although promising, it requires the impartial approach and certain precautions.
\end{abstract}

Key words: Advanced age - Glucocorticoids - Cardiovascular parameters - Hemodynamics - Soy isoflavones

\begin{abstract}
Abbreviations: CO, cardiac output; DHEA, dehydroepiandrosterone; DHEAS, dehydroepiandrosterone sulphate; HPA, hypothalamo-pituitary-adrenal; $3 \beta$-HSD, 3- $\beta$-hydroxysteroid dehydrogenase; LDL, low-density lipoprotein; MetS, metabolic syndrome; P450c21, cytochrome P-450 21-hydroxylase; PPAR, peroxisome-proliferator activating receptor.
\end{abstract}

\section{Impairment of central regulation of glucocorticoid secretion with aging}

The hypothalamo-pituitary-adrenal (HPA) system is involved in stress response and represents the central point of the endocrine, nervous and immune systems integration (Ferrari et al. 2001). Endogenous glucocorticoids are

Correspondence to: Vladimir Z. Ajdžanović, Institute for Biological Research "Siniša Stanković", University of Belgrade, 142 Despot Stefan Blvd., 11060 Belgrade, Serbia

E-mail: avlada@ibiss.bg.ac.rs produced in the adrenal glands cortex and, in a circadian manner, secreted into the circulation, showing a tendency to elevate in response to stress and disease. It has been proposed that increased HPA system activity followed by elevated glucocorticoids may contribute to lower bone mineral density (Greendale at al. 1999), and to the pathogenesis of the metabolic syndrome (MetS) characterized by insulin resistance coherent with hyperglycemia and "bad" profile of blood lipids, visceral fat accumulation and hypertension (Obunai et al. 2007; Ørgaard and Jensen 2008; Anagnosits et al. 2009). Advanced age is followed by synaptic/neuronal loss and impaired central regulation of adrenocortical secretion, 


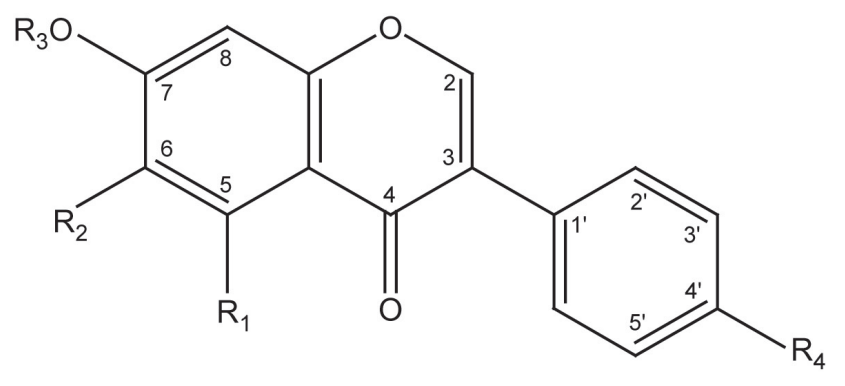

\begin{tabular}{lllll}
\hline Isoflavone & $\mathrm{R}_{1}$ & $\mathrm{R}_{2}$ & $\mathrm{R}_{3}$ & $\mathrm{R}_{4}$ \\
\hline Genistein & $\mathrm{OH}$ & $\mathrm{H}$ & $\mathrm{H}$ & $\mathrm{OH}$ \\
Daidzein & $\mathrm{H}$ & $\mathrm{H}$ & $\mathrm{H}$ & $\mathrm{OH}$ \\
Glycitein & $\mathrm{H}$ & $\mathrm{OCH}_{3}$ & $\mathrm{H}$ & $\mathrm{OH}$ \\
Formononetin & $\mathrm{H}$ & $\mathrm{H}$ & $\mathrm{H}$ & $\mathrm{OCH}_{3}$ \\
Biochanin $\mathrm{A}$ & $\mathrm{OH}$ & $\mathrm{H}$ & $\mathrm{H}$ & $\mathrm{OCH}_{3}$ \\
Genistin & $\mathrm{OH}$ & $\mathrm{H}$ & $\mathrm{Glu}$ & $\mathrm{OH}$ \\
Daidzin & $\mathrm{H}$ & $\mathrm{H}$ & $\mathrm{Glu}$ & $\mathrm{OH}$ \\
Glycitin & $\mathrm{H}$ & $\mathrm{OCH}_{3}$ & $\mathrm{Glu}$ & $\mathrm{OH}^{-}$ \\
Ononin & $\mathrm{H}$ & $\mathrm{H}$ & $\mathrm{Glu}$ & $\mathrm{OCH}_{3}$ \\
Sissotrin & $\mathrm{OH}$ & $\mathrm{H}$ & $\mathrm{Glu}$ & $\mathrm{OCH}_{3}$ \\
\hline
\end{tabular}

Figure 1. The general formula of soy isoflavones and related glucosides.

leading to a significant increase in the glucocorticoids/adrenal androgens ratio (Ferrari et al. 2001; Nichols et al. 2001; Rosenzweig and Barnes 2003) which is consistent with the large prevalence of MetS at this age (Akbaraly et al. 2011). And vice versa, there is evidence that high levels of glucocorticoids contribute to degenerative changes in certain brain regions and to cognitive disorders during aging in some individuals (Nichols et al. 2001). Finally, age-related decrease of adrenal androgens secretion results in the loss of anti-glucocorticoid protection and leads to enhanced neurotoxicity and structural damage in the hippocampus (McEwen 1999; Ferrari et al. 2001).

\section{Altered hemodynamics in advanced age}

Various parameters of hemodynamics or "blood movement", including cardiac output (CO), circulating blood volume, vascular diameter/resistance and blood viscosity, all influencing blood pressure, show a tendency to deteriorate during ageing. Such pathological changes are further pronounced in conditions like obesity, hyperlipidemia and atherosclerosis, which are inherent to MetS and advanced age. In obese patients a high prevalence of hypertension has been suggested (Zhang and Reisin 2000) associated with increased $\mathrm{CO}$ and peripheral vascular resistance (Redon
2001). These changes lead to left ventricular hypertrophy, which provides the basis for the development of cardiac arrhythmias and heart failure (Zhang and Reisin 2000). Atherosclerosis is a complex multifactorial disease whose pathogenesis involves smooth muscle-cell proliferation, lipid deposition, thrombosis and calcification (Wilcox and Blumenthal 1995). Atherosclerotic plaques de facto represent mechanical barriers to blood flow, significantly disrupting the hemodynamics. The fluidity of erythrocyte membrane, representing the feature that defines erythrocyte deformability/blood viscosity (Cartwright et al. 1985; Zicha et al. 1999), is compromised in hypertension and atherosclerosis. Namely, membrane fluidity of erythrocytes is significantly lower in both spontaneously hypertensive rats and patients with essential hypertension, in comparison to normotensive controls (Tsuda et al. 1987; Tsuda 2010). It was observed that low erythrocyte membrane fluidity negatively affects erythrocyte deformability/blood viscosity (Cartwright et al. 1985; Heilmann et al. 1994). Finally, glucocorticoid excess may also disturb hemodynamics in advanced age, by contributing to the development of some MetS symptoms (Yanovski and Cutler 1994; Friedman et al. 1996; Anagnostis et al. 2009).

\section{Soy isoflavones: the extent of potential benefits}

\section{General considerations}

Humans are introduced to biologically active isoflavones via diet, primarily soy-derived foods, and dietary supplements which contain high levels of these estrogen-like diphenolic compounds (Price and Fenwick 1985; Adlercreutz and Mazur 1997). Weak estrogenic and antiestrogenic activity was observed following soy isoflavone application, both in vivo and in vitro (Price and Fenwick 1985). In addition, soy isoflavones exhibit strong antioxidative activity (Benassayag et al. 2002) as well as tyrosine kinase inhibiting effects (Akiyama et al. 1987).

Elaboration of soy isoflavones effects on glycemic status indicates the distinction between in vitro and in vivo data. Soy isoflavone genistein is able to enhance insulin secretion in some cell lines as well as in isolated mouse and rat pancreatic islets (Sorenson et al. 1994; Jonas et al. 1995; Szkudelska and Nogowski 2007). The observed effect is shown to be estrogen receptor- and tyrosine kinase-independent. However, it was found that genisteins' insulinotropic activity, in cell lines and pancreatic islets, is based on cAMP increase and protein kinase A activation (Liu et al. 2006; Szkudelska and Nogowski 2007). Contrary to the in vitro observations, results of in vivo studies indicate that genistein does not increase blood insulin. Namely, it causes the lowering of circulating insulin in rats and post-menopausal women (Szkudelska et al. 2003; 


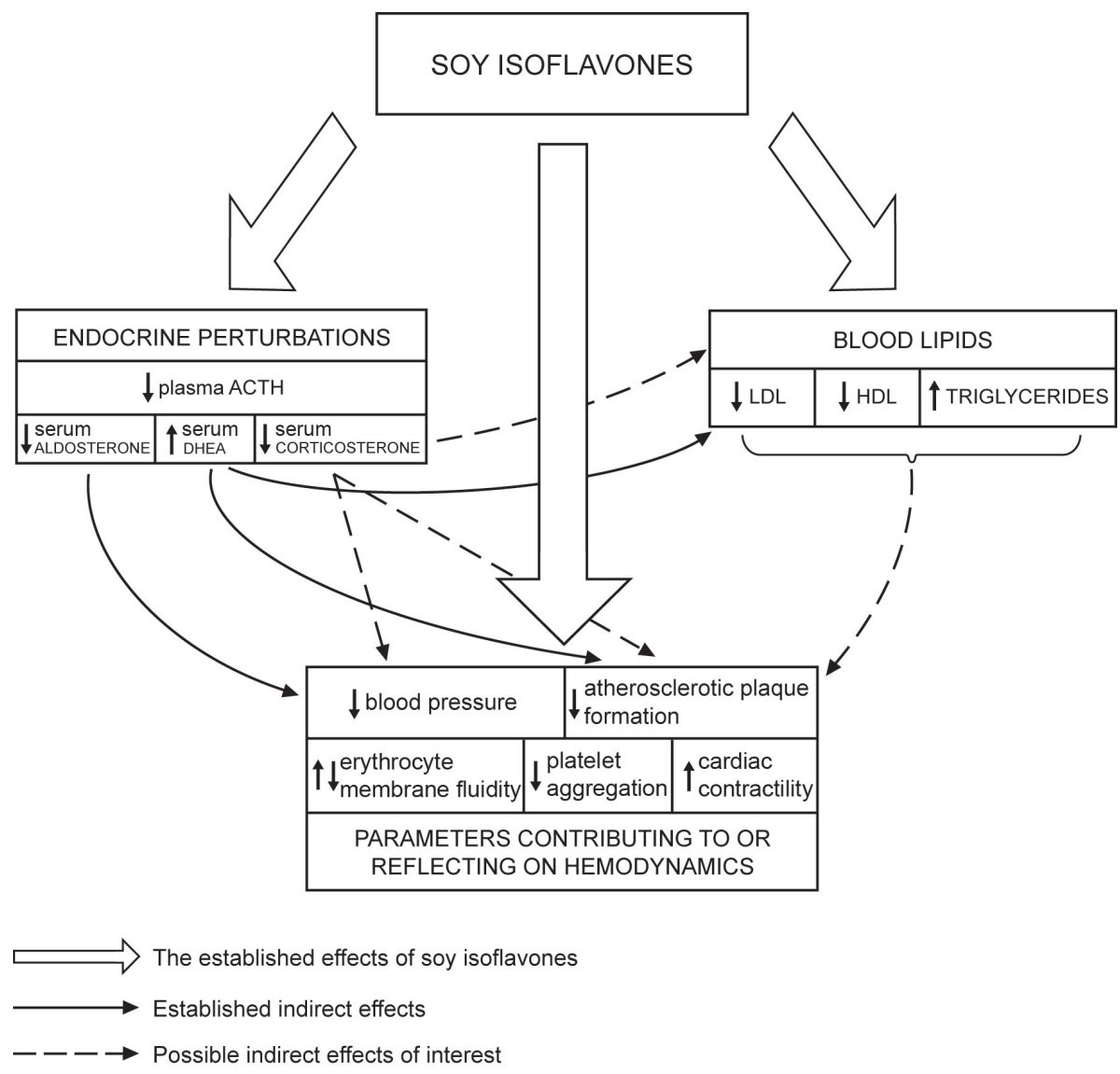

Figure 2. The effects of soy isoflavones on hemodynamics, endocrine perturbations, and blood lipids. ACTH, adrenocorticotropic hormone; DHEA, dehydroepiandrosterone; LDL, low-density lipoprotein; HDL, high-density lipoprotein.

Cheng et al. 2004; Lephart et al. 2004). Also, it should be mentioned that genistein, in some animal models, reduces lipoprotein lipase gene expression in adipose tissue, which contributes to diminished lipid uptake by fat cells and to the prominent anti-obesity effects (Naaz et al. 2003).

A significant amount of research interest has been focused on the effectiveness of soy isoflavones as natural therapeutics for cardiovascular problems. It was suggested that estrogens reduce morbidity related to coronary artery disease in postmenopausal women (Sullivan and Fowlkes 1996). Unfortunately, later on it was observed that the application of estrogens in parallel may increase the risk for thromboembolism or cancer development (Grady et al. 2000; Fournier et al. 2003), which dampened the enthusiasm for their application. Early studies on soy isoflavones, introduced as an alternative to estrogens, suggested that they may decrease the level of cholesterol in serum (Setchell 1985), as well as slow down the atherosclerotic plaques formation by inhibiting cell adhesion and by altering the activity of specific growth factors (Raines and Ross 1995). Also, it was shown that acute and 2-day treatment with genistein increases cardiac contractility in isolated working rat hearts (Al-Nakkash et al. 2009), suggesting effects of genistein on CO. Our results on middle-aged male rats indicate that genistein and the related compound - daidzein decrease serum cholesterol, but increase the triglycerides level (Šošić-Jurjević et al. 2007). The up-regulation of lowdensity lipoprotein (LDL) receptors and the inhibition of endogenous cholesterol synthesis are the most probable explanations for the observed effects (Tham et al. 1998). Demarcation between the soy isoflavone and soy protein effects per se in the lipid profile is not entirely clear. Some data suggest that soy proteins are principally responsible for the blood lipid-lowering effects of soy (Wagner et al. 2000), via up-regulation of the expression of hepatic thyroid hormone receptor $\beta 1$ involved in cholesterol metabolism (Xiao et al. 2004). The fact is that the removal of the isoflavone fraction from soy protein results in the loss of its beneficial effect in hypercholesterolemic subjects (Gardner et al. 2001). It has been proposed that soy isoflavones exert their hypocholesterolemic and anti-atherosclerotic activity by acting as peroxisome-proliferator activating receptor (PPAR) 
agonists (Mezei et al. 2003). PPAR are nuclear receptors that regulate the transcription of genes involved in lipid metabolism within the cell. Finally, it was suggested that genistein and daidzein could inhibit platelet aggregation by acting as thromboxane A2 membrane receptor antagonists (Nakashima et al. 1991), which may prevent the thrombus formation.

\section{Effects on corticosteroid secretion and potential implications}

Some studies suggest that soy isoflavones prevent chemically-induced hippocampal neuronal loss (Azcoitia et al. 2006). Presumably, given the importance of hippocampus in the regulation of corticosteroid secretion, as well as its deterioration during ageing, soy isoflavones may have the potential to prevent glucocorticoid excess in advanced age. Genistein and daidzein are the prominent inhibitors of $3 \beta$ HSD and cytochrome P-450 21-hydroxylase (P450c21) enzymes, thus directly affecting adrenocortical steroidogenesis (Ohno et al. 2002; 2003). The results from different animal studies suggest that subcutaneous administration of various doses of genistein $(3 \mathrm{nmol} / 100 \mathrm{~g} /$ day- $0.11 \mathrm{mmol} / \mathrm{kg} /$ day) decreases the circulating levels of both adrenocorticotropic hormone (ACTH) and corticosterone (Malendowicz et al. 2006; Ajdžanović et al. 2009a; Milošević et al. 2009). In addition, genistein causes the shunting of steroid metabolic pathways in the adrenals by favoring dehydroepiandrosterone (DHEA) and inhibiting cortisol/corticosterone and aldosterone production in vitro, as well as in vivo in an animal model of the andropause (Mesiano et al. 1999; Sirianni et al. 2001; Ajdžanović et al. 2009b). Daidzein, which comprises a slight but very important structural difference when compared to genistein (the lack of C5 hydroxyl group), applied in a dose of $0.12 \mathrm{mmol} / \mathrm{kg} /$ day, also lowers ACTH and corticosterone levels in andropausal rats (Ajdžanović et al. 2011b). The doses of genistein or daidzein, employed in the studies of andropause, were chosen to mimic human exposure to elevated concentrations of isoflavones when nutritional supplements are used for therapeutic purposes (Doerge and Sheehan 2002). It is important to note that soy isoflavones alter adrenocortical steroid production without affecting the expression of steroidogenic enzymes, most likely by modulating steroidogenic enzyme and tyrosine kinase activities (Bodart et al. 1995; Mesiano et al. 1999). Considering previously elaborated roles of glucocorticoids in MetS and hemodynamic alterations, their decrease following soy isoflavone application may represent a significant therapeutical goal. It is noteworthy that angiotensin-converting enzyme inhibitors, which block the renin-angiotensin-aldosterone system involved in the pathogenesis of hypertension and heart failure, have been recognized as a therapy of choice in hypertension and heart failure (Verdecchia et al. 2012). The well established role of genistein in the inhibition of aldosterone synthesis (Sirianni et al. 2001; Ajdžanović et al. 2009b) reinforces the idea of the application of soy isoflavones in hypertension treatment. Pertinent to this, we have observed a several-fold increase in DHEA levels in middle-aged male rats following the treatment with genistein (Ajdžanović et al. 2009b). Some prospective population-based studies suggest that androgens are not significantly associated with the cardiovascular risks (Barrett-Connor and Khaw 1988), but on the other hand have been reported to elevate blood pressure in spontaneously hypertensive rats (Martin et al. 2005). High adrenal androgens, DHEA and dehydroepiandrosterone sulphate (DHEAS), have been suggested to be cardioprotective, while DHEA supplementation was reported to reduce cholesterol levels and atherosclerotic plaque formation in humans and animal models (Khaw 1996). Also, some clinical studies indicate that several months of treatment with DHEA is safe for older women when it comes to cardiovascular risk factors (Boxer et al. 2010). Conversely, the results on DHEAS showed increased cardiovascular risks in a population with "bad life habits" (Hautanen et al. 1994). Hence, further research addressing DHEA(S) clinical potentials as well as their roles in the effects of soy isoflavones remains a challenge. Certainly, in a broader context of the therapeutic strategies consideration, some isoflavone antiandrogen effects (Lund et al. 2004, 2011) and the potential implications on cardiovascular health should not be disregarded.

\section{Direct effects on hemodynamics}

A randomized controlled trial showed that increased dietary soy intake lowers blood pressure in hypertensives independently of age, gender, and weight variations, alcohol intake, or urinary sodium and potassium levels (Burke et al. 2001). Another study showed that long-term soy supplementation in male and post-menopausal female subjects significantly reduced systolic, diastolic and mean arterial pressure, which may be attributed, at least partially, to the observed decrease in peripheral vascular resistance (Teede et al. 2001). However, at the same time there were some indications of adverse cardiovascular effects. In a subsequent study, Teede's group found that the application of soy isoflavone formononetin (a precursor of daidzein) in a similar group of subjects resulted in the reduction of total peripheral resistance (Teede et al. 2003). When it comes to the soy isoflavones-caused vasomotor effects, it seems that endothelium-dependent, as well as, endothelium-independent mechanisms are operative. Various animal and human studies suggest that soy isoflavones-influenced vasorelaxation is nitric oxide (NO)dependent (Vera et al. 2005; Hall et al. 2008), although, it has been observed that a soy rich diet does not affect the level of endothelial NO synthase (Schreihofer et al. 2010). On the 
other hand, daidzein was reported to cause vasorelaxation by significantly increasing the conductance of $\mathrm{Ca}^{2+}{ }_{\text {-acti- }}$ vated $\mathrm{K}^{+}$channels in vascular smooth muscle cells (Zhang et al. 2010). The effects on peripheral circulation could be explained by the influence of soy isoflavones on erythrocyte membrane fluidity, which affects erythrocyte deformability/blood viscosity. We have shown recently that daidzein provokes a significant increase in the fluidity of deeper layers of erythrocyte membrane (Ajdžanović et al. 2010). In contrast, the more hydrophilic genistein induced a decrease in erythrocyte membrane fluidity near the hydrophilic surface (Ajdžanović et al. 2010). Clearly, the number and polarity of functional groups in soy isoflavones and their glucosilated forms determinate the positioning of these compounds in the erythrocyte membrane, which reflects on the membrane molecular order and, consequently, on its fluidity. Isoflavone $\beta$-glucosides-rich soy extract acted in a similar fashion to genistein on the erythrocyte membrane fluidity, which may have negative implications on erythrocyte rheologic behavior/blood viscosity (Ajdžanović et al. 2011a). It is known that the isoflavone content and profiles in soy may vary considerably in relation to soy variety and geographic and environmental conditions, as well as to the mode of industrial processing (Cassidy et al. 2000; De Lima Toccafondo Vieira et al. 2008), which may account for the inconsistent results of in vivo studies. This implies that soy isoflavone extracts should not be used as an end-product applicable in human treatment, but that more effort should be invested in finding specific component(s) responsible for beneficial, as well as for adverse effects. According to the available data, soy products showing high levels of daidzein and low levels of genistein and isoflavone $\beta$-glucosides could be a more beneficial component of the diet of patients with cardiovascular diseases.

\section{Conclusion}

Soy isoflavones exert effects on the hemodynamics directly, as well as indirectly, via endocrine perturbations. It was shown that soy isoflavones may reverse the glucocorticoids/ adrenal androgens ratio, frequently disturbed in advanced age. The algorithm of soy isoflavones effects in this field, besides beneficial, comprises some with the negative sign (e.g. increased triglyceride levels) as well as effects with ambiguous implications (in the domain of androgens). Differences between the effects during developmental $v s$. advanced phases of hypertension and the functional role of soy isoflavones chemical structure should particularly be taken into account. When considering the results of in vitro and animal studies, and comparing them with those in human studies, it should be noted that the differences exist (e.g. the effects of genistein on insulin secretion), and that certain, physiologically relevant, metabolic conversions of soy isoflavones do not affect the entire human population (e.g. daidzein conversion to equol occurs only in $30-40 \%$ of humans). It can be concluded that advantages in soy isoflavones-based therapy of glucocorticoid excess and disturbed hemodynamics in advanced age exist, but the development of potential therapeutics requires a balanced and impartial approach.

Acknowledgement. This work was supported by the Ministry of Education, Science and Technological Development of the Republic of Serbia, Grant numbers 173009 and 173014.

\section{References}

Adlercreutz H., Mazur W. (1997): Phyto-oestrogens and Western diseases. Ann. Med. 29, 95-120

Ajdžanović V., Šošić-Jurjević B., Filipović B., Trifunović S., Brkić D., Sekulić M., Milošević V. (2009a): Genistein affects the morphology of pituitary ACTH cells and decreases circulating levels of ACTH and corticosterone in middle-aged male rats. Biol. Res. 42, 13-23

Ajdžanović V., Šošić-Jurjević B., Filipović B., Trifunović S., Manojlović-Stojanoski M., Sekulić M., Milošević V. (2009b): Genistein-induced histomorphometric and hormone secreting changes in the adrenal cortex in middle-aged rats. Exp. Biol. Med. 234, 148-156

http://dx.doi.org/10.3181/0807-RM-231

Ajdžanović V., Spasojević I., Filipović B., Šošić-Jurjević B., Sekulić M., Milošević V. (2010): Effects of genistein and daidzein on erythrocyte membrane fluidity: an electron paramagnetic resonance study. Can. J. Physiol. Pharmacol. 88, 497-500 http://dx.doi.org/10.1139/Y10-020

Ajdžanović V., Spasojević I., Šošić-Jurjević B., Filipović B., Trifunović S., Sekulić M., Milošević V. (2011a): The negative effect of soy extract on erythrocyte membrane fluidity: an electron paramagnetic resonance study. J. Membrane Biol. 239, 131-135 http://dx.doi.org/10.1007/s00232-010-9332-8

Ajdžanović V., Šošić-Jurjević B., Filipović B., Trifunović S., Milošević V. (2011b): Daidzein effects on ACTH cells: immunohistomorphometric and hormonal study in an animal model of the andropause. Histol. Histopathol. 26, 1257-1264

Akbaraly T. N., Ancelin M. N., Jaussent I., Ritchie C., Barberger-Gateau P., Dufouil C., Kivimaki M., Berr C., Ritchie K. (2011): Metabolic syndrome and onset of depressive symptoms in the elderly: findings from the three-city study. Diabetes Care 34, 904-909 http://dx.doi.org/10.2337/dc10-1644

Akiyama T., Ishida J., Nakagawa S., Ogawara H., Watanabe S., Itoh N., Shibuya M., Fukami Y. (1987): Genistein, a specific inhibitor of tyrosine-specific protein kinases. J. Biol. Chem. 262, 5592-5595

Al-Nakkash L., Markus B., Bowden K., Batia L. M., Prozialeck W. C., Broderick T. L. (2009): Effects of acute and 2-day genistein treatment on cardiac function and ischemic tolerance in ovariectomized rats. Gend. Med. 6, 488-497 http://dx.doi.org/10.1016/j.genm.2009.09.004 
Anagnostis P., Athyros V. G., Tziomalos K., Karagiannis A., Mikhailidis D. P. (2009): Clinical review: The pathogenic role of cortisol in the metabolic syndrome: a hypothesis. J. Clin. Endocrinol. Metab. 94, 2692-2701 http://dx.doi.org/10.1210/jc.2009-0370

Azcoitia I., Moreno A., Carrero P., Palacios S., Garcia-Segura L. M. (2006): Neuroprotective effects of soy isoflavones in the rat brain. Gynecol. Endocrinol. 22, 63-69 http://dx.doi.org/10.1080/09513590500519161

Barrett-Connor E., Khaw K. T. (1988): Endogenous sex hormones and cardiovascular disease in men. A prospective populationbased study. Circulation 78, 539-545 http://dx.doi.org/10.1161/01.CIR.78.3.539

Benassayag C., Perrot-Applanat M., Ferre F. (2002): Phytoestrogens as modulators of steroid action in target cells. J. Chromatogr. B Analyt. Technol. Biomed. Life Sci. 777, 233-248 http://dx.doi.org/10.1016/S1570-0232(02)00340-9

Bodart V., Ong H., De Lean A. (1995): A role for protein tyrosine kinase in the steroidogenic pathway of angiotensin II in bovine zona glomerulosa cells. J. Steroid Biochem. Mol. Biol. $\mathbf{5 4}, 55-62$ http://dx.doi.org/10.1016/0960-0760(95)00077-D

Boxer R. S., Kleppinger A., Brindisi J., Feinn R., Burleson J. A., Kenny A. M. (2010): Effects of dehydroepiandrosterone (DHEA) on cardiovascular risk factors in older women with frailty characteristics. Age Ageing 39, 451-458 http://dx.doi.org/10.1093/ageing/afq043

Burke V., Hodgson J. M., Beilin L. J., Giangiulioi N., Rogers P., Puddeu I. B. (2001): Dietary protein and soluble fiber reduce ambulatory blood pressure in treated hypertensives. Hypertension 38, 821-826 http://dx.doi.org/10.1161/hy1001.092614

Cartwright I. J., Pockley A. G., Galloway J. H., Greaves M., Preston F. E. (1985): The effects of dietary omega-3 polyunsaturated fatty acids on erythrocyte membrane phospholipids, erythrocyte deformability and blood viscosity in healthy volunteers. Atherosclerosis 55, 267-281 http://dx.doi.org/10.1016/0021-9150(85)90106-6

Cassidy A., Hanley B., Lamuela-Raventos R. M. (2000): Isoflavones, lignans and stilbenes-origins, metabolism and potential importance to human health. J. Sci. Food Agric. 80, 1044-1062 http://dx.doi.org/10.1002/(SICI)1097-0010(20000515)80:7<1044: AID-JSFA586 >3.0.CO;2-N

Cheng S. Y., Shaw N. S., Tsai K. S., Chen C. Y. (2004): The hypoglicemic effects of soy isoflavones on postmenopausal woman. J. Women Health (Larchmt) 13, 1080-1086 http://dx.doi.org/10.1089/jwh.2004.13.1080

De Lima Toccafondo Vieira M., Ferreira Duarte R., Moreira Campos L. M., Nunan Ede A. (2008): Comparison of the estrogenic potencies of standardized soy extracts by immature rat uterothropic bioassay. Phytomedicine 15, 31-37 http://dx.doi.org/10.1016/j.phymed.2007.06.006

Doerge D., Sheehan D. (2002): Goitrogenic and estrogenic activity of soy isoflavones. Environ. Health Perspect. 110, 349-353 http://dx.doi.org/10.1289/ehp.02110s3349

Ferrari E., Cravello L., Muzzoni B., Casarotti D., Paltro M., Solerte S. B., Fioravanti M., Cuzzoni G., Pontiggia B., Magri F. (2001): Age-related changes of the hypothalamic-pituitary-adrenal axis: pathophysiological correlates. Eur. J. Endocrinol. 144, 319-329

http://dx.doi.org/10.1016/S0165-0173(01)00133-3

Fournier A., Hill C., Clavel-Chapelon F. (2003): Hormone replacement therapy in menopause and risk of breast cancer. Bull. Cancer 90, 821-831

Friedman T. C., Mastorakos G., Newman T. D., Mullen N. M., Horton E. G., Costello R., Papadopoulos D. P., Chrousos G. P. (1996): Carbohydrate and lipid metabolism in endogenous hypercortisolism: shared features with metabolic syndrome $\mathrm{X}$ and NIDDM. Endocr. J. 43, 645-655 http://dx.doi.org/10.1507/endocrj.43.645

Gardner C. D., Newell K. A., Cherin R., Haskell W. L. (2001): The effect of soy protein with or without isoflavones relative to milk protein on plasma lipids in hypercholesterolemic postmenopausal women. Am. J. Clin. Nutr. 73, 728-735

Grady D., Wenger N. K., Herrington D., Khan S., Furberg C., Hunninghake D., Vittinghoff E., Hulley S. (2000): Postmenopausal hormone therapy increases risk for venous thromboembolic disease. The Heart and Estrogen/progestin Replacement study. Ann. Intern. Med. 132, 689-696 http://dx.doi.org/10.1097/00006254-200011000-00021

Greendale G. A., Unger J. B., Rowe J. W., Seeman T. E. (1999): The relation between cortisol excretion and fractures in healthy older people: results from the MacArthur studies-Mac. J. Am. Geriatr. Soc. 47, 799-803

Hall W. L., Formanuik N. L., Harnpanich D., Cheung M., Talbot D., Chowienczyk P. J., Sanders T. A. (2008): A meal enriched with soy isoflavones increases nitric oxide-mediated vasodilation in healthy postmenopausal women. J. Nutr. 138, $1288-1292$

Hautanen A., Mänttäri M., Manninen V., Tenkanen L., Huttunen J. K., Frick M. H., Adlercreutz H. (1994): Adrenal androgens and testosterone as coronary risk factors in the Helsinki Heart Study. Atherosclerosis 105, 191-200 http://dx.doi.org/10.1016/0021-9150(94)90049-3

Heilmann L., Hojnacki B., von Tempelhoff G. F. (1994): Red cell deformability in gestational hypertension. Gynecol. Obstet. Invest. 37, 155-159 http://dx.doi.org/10.1159/000292547

Jonas J. C., Plant T. D., Gilon P., Detimary P., Nenquin M., Henquin J. C. (1995): Multiple effects and stimulation of insulin secretion by the tyrosine kinase inhibitor genistein in normal mouse islets. Br. J. Pharmacol. 114, 872-880 http://dx.doi.org/10.1111/j.1476-5381.1995.tb13285.x

Khaw K. T. (1996): Dehydroepiandrosterone, dehydroepiandrosterone sulphate and cardiovascular disease. J. Endocrinol. 150, S149-153

Lephart E. D., Porter J. P., Lund T. D., Bu L., Setchell K. D. R., Ramoz G., Crowley W. R. (2004): Dietary isoflavones alter regulatory behaviors, metabolic hormones and neuroendocrine function in Long-Evans male rats. Nutr. Metab. 1, 1-14 http://dx.doi.org/10.1186/1743-7075-1-16

Liu D., Zhen W., Yang Z., Carter J. D., Si H., Reynolds K. A. (2006): Genistein acutely stimulates insulin secretion in pancreatic $\beta$-cells through a cAMP-dependent protein kinase pathway. Diabetes 55, 1043-1050 http://dx.doi.org/10.2337/diabetes.55.04.06.db05-1089 
Lund T. D., Munson D. J., Haldy M. E., Setchell K. D., Lephart E. D., Handa R. J. (2004): Equol is a novel anti-androgen that inhibits prostate growth and hormone feedback. Biol. Reprod. 70, 1188-1195 http://dx.doi.org/10.1095/biolreprod.103.023713

Lund T. D., Blake C., Bu L., Hamaker A. N., Lephart E. D. (2011): Equol an isoflavonoid: potential for improved prostate health, in vitro and in vivo evidence. Reprod. Biol. Endocrinol. 9, 4 http://dx.doi.org/10.1186/1477-7827-9-4

Malendowicz L. K., Trejter M., Rebuffat P., Ziolkowska A., Nussdorfer G. G., Majchrzak M. (2006): Effects of some endocrine disruptors on the secretory and proliferative activity of the regenerating rat adrenal cortex. Int. J. Mol. Med. 18, 197-200

Martin D. S., Biltoft S., Redetzke R., Vogel E. (2005): Castration reduces blood pressure and autonomic venous tone in male spontaneously hypertensive rats. J. Hypertens. 23, 2229-2236 http://dx.doi.org/10.1097/01.hjh.0000191903.19230.79

McEwen B. S. (1999): Stress and aging hippocampus. Front. Neuroendocrinol. 20, 49-70 http://dx.doi.org/10.1006/frne.1998.0173

Mesiano S., Katz S. L., Lee J. Y., Jaffe R. B. (1999): Phytoestrogens alter adrenocortical function: genistein and daidzein suppress glucocorticoid and stimulate androgen production by cultured adrenal cortical cells. J. Clin. Endocrinol. Metab. 84, 2443-2448 http://dx.doi.org/10.1210/jc.84.7.2443

Mezei O., Banz W. J., Steger R. W., Peluso M. R., Winters T. A., Shay N. (2003): Soy isoflavones exert antidiabetic and hypolipidemic effects through the PPAR pathways in obese Zucker rats and murine RAW 264.7 cells. J. Nutr. 133, 1238-1243

Milošević V., Ajdžanović V., Šošić-Jurjević B., Filipović B., Brkić M., Nestorović N., Sekulić M. (2009): Morphofunctional characteristics of ACTH cells in middle-aged male rats after treatment with genistein. Gen. Physiol. Biophys. 28, 94-97 http://dx.doi.org/10.4149/gpb_2009_01_94

Naaz A., Yellayi S., Zakroczymski M. A., Bunick D., Doerge D. R., Lubahn D. B., Helferich W. G., Cooke P. S. (2003): The soy isoflavone genistein decreases adipose deposition in mice. Endocrinology 144, 3315-3320 http://dx.doi.org/10.1210/en.2003-0076

Nakashima S., Koike T., Nozawa Y. (1991): Genistein, a protein tyrosine kinase inhibitor, inhibits thromboxane A2-mediated human platelet responses. Mol. Pharmacol. 39, 475-480

Nichols N. R., Zieba M., Bye N. (2001): Do glucocorticoids contribute to brain aging? Brain Res. Rev. 37, 273-286 http://dx.doi.org/10.1016/S0165-0173(01)00131-X

Obunai K., Jani S., Dangas G. D. (2007): Cardiovascular morbidity and mortality of the metabolic syndrome. Med. Clin. North Am. 91, 1169-1184 http://dx.doi.org/10.1016/j.mcna.2007.06.003

Ohno S., Shinoda S., Toyoshima S., Nakazawa H., Makino T., Nakajin S. (2002): Effects of flavonoid phytochemicals on cortisol production and on activities of steroidogenic enzymes in human adrenocortical H295R cells. J. Steroid Biochem. Mol. Biol. 80, 355-363 http://dx.doi.org/10.1016/S0960-0760(02)00021-3

Ohno S., Nakajima Y., Inoue K., Nakazawa H., Nakajin S. (2003): Genistein administration decreases serum corticosterone and testosterone levels in rats. Life Sci. 74, 733-742 http://dx.doi.org/10.1016/j.lfs.2003.04.006

Ørgaard A., Jensen L. (2008): The effects of soy isoflavones on obesity. Exp. Biol. Med. 233, 1066-1080 http://dx.doi.org/10.3181/0712-MR-347

Price K. R., Fenwick G. R. (1985): Naturally occuring oestrogens in foods-a review. Food Addit. Contam. 2, 73-106 http://dx.doi.org/10.1080/02652038509373531

Raines E. W., Ross R. (1995): Biology of atherosclerotic plaque formation: possible role of growth factors in lesion development and the impact of soy. J. Nutr. 125, S624-630

Redon J. (2001): Hypertension in obesity. Nutr. Metab. Cardiovasc. Dis. 11, 344-353

Rosenzweig E. S., Barnes C. A. (2003): Impact of ageing on hippocampal function: plasticity, network dynamics, and cognition. Prog. Neurobiol. 69, 143-179 http://dx.doi.org/10.1016/S0301-0082(02)00126-0

Schreihofer D. A., Deutsch C., Lovekamp-Swan T., Sullivan J. C., Dorrance A. M. (2010): Effect of high soy diet on the cerebrovasculature and endothelial nitric oxid synthase in the ovariectomized rat. Vascul. Pharmacol. 52, 236-242 http://dx.doi.org/10.1016/j.vph.2010.02.003

Setchell K. D. R. (1985): Naturally occurring non-steroidal estrogens of dietary origin. In: Estrogens in the Environment: Influence on Development. (Eds. J. McLachlan), pp. 69-85, Elsevier, New York

Sirianni R., Carr B. R., Pezzi V., Rainey W. E. (2001): A role for src tyrosine kinase in regulating adrenal aldosterone production. J. Mol. Endocrinol. 26, 207-215

http://dx.doi.org/10.1677/jme.0.0260207

Sorenson R. L., Brelje T. C., Roth C. (1994): Effects of tyrosine kinase inhibitors on islets of Langerhans: evidence for tyrosine kinases in the regulation of insulin secretion. Endocrinology 134, 1975-1978 http://dx.doi.org/10.1210/en.134.4.1975

Sullivan J. M., Fowlkes L. P. (1996): Estrogens, menopause, and coronary artery disease. Cardiol. Clin. 14, 105-116 http://dx.doi.org/10.1016/S0733-8651(05)70264-2

Szkudelska K., Nogowski L., Kaczmarek P., Pruszynska-Oszmalek E., Szkudelski R., Sieczka A., Szkudelski T. (2003): Hormonal and metabolic effects of genistein and daidzein in male rats. J. Anim. Feed Sci. 12, 839-847

Szkudelska K., Nogowski L. (2007): Genistein-A dietary compound inducing hormonal and metabolic changes. J. Steroid Biochem. Mol. Biol. 105, 37-45 http://dx.doi.org/10.1016/j.jsbmb.2007.01.005

Šošić-Jurjević B., Filipović B., Ajdžanović V., Brkić D., Ristić N., Manojlović-Stojanoski M., Nestorović N., Trifunović S., Sekulić M. (2007): Subcutaneously administered genistein and daidzein decrease serum cholesterol and increase triglyceride levels in male middle-aged rats. Exp. Biol. Med. 232, 1222-1227 http://dx.doi.org/10.3181/0703-BC-82

Teede H. J., Dalais F. S., Kotsopoulos D., Liang Y. L., Davis S., McGrath B. P. (2001): Dietary soy has both benefitial and potentially adverse cardiovascular effects: a placebo-controlled study in men and postmenopausal women. J. Clin. Endocrinol. Metab. 86, 3053-3060 http://dx.doi.org/10.1210/jc.86.7.3053 
Teede H. J., McGrath B. P., DeSilva L., Cehun M., Fassoulakis A., Nestel P. J. (2003): Isoflavones reduce arterial stiffness: a placebo-controlled study in men and postmenopausal women. Arterioscler. Thromb. Vasc. Biol. 23, 1066-1071 http://dx.doi.org/10.1161/01.ATV.0000072967.97296.4A

Tham D. M., Gardner C. D., Haskell W. L. (1998): Potential health benefits of dietary phytoestrogens: a review of the clinical, epidemiological, and mechanistic evidence. J. Clin. Endocrinol. Metab. 83, 2223-2235 http://dx.doi.org/10.1210/jc.83.7.2223

Tsuda K., Iwahashi H., Minatogawa Y., Nishio I., Kido R., Masuyama Y. (1987): Electron spin resonance studies of erythrocytes from spontaneously hypertensive rats and humans with essential hypertension. Hypertension 9, III19-24 http://dx.doi.org/10.1536/ihj.28.923

Tsuda K. (2010): Oxidative stress and membrane fluidity of red blood cells in hypertensive and normotensive men. An electron spin resonance investigation. Int. Heart J. 51, $121-124$ http://dx.doi.org/10.1536/ihj.51.121

Vera R., Galisteo M., Villar I. C., Sánchez M., Zarzuelo A., Pérez-Vizcaíno F., Duarte J. (2005): Soy isoflavones improve endothelial function in spontaneously hypertensive rats in an estrogen independent manner: role of nitric-oxid synthase, superoxide, and cyclooxigenase metabolites. J. Pharmacol. Exp. Ther. 314, 1300-1309 http://dx.doi.org/10.1124/jpet.105.085530

Verdecchia P., Gentile G., Angeli F., Reboldi G. (2012): Beyond blood pressure: evidence for cardiovascular, cerebrovascular, and renal protective effects of renin-angiotensin system blockers. Ther. Adv. Cardiovasc. Dis. 6, 81-91 http://dx.doi.org/10.1177/1753944712444866
Wagner J. D., Zhang L., Greaves K. A., Shadoan M. K., Schwenke D. C. (2000): Soy protein reduces the arterial low-density lipoprotein (LDL) concentration and delivery of LDL cholesterol to the arteries of diabetic and nondiabetic male cynomolgus monkeys. Metabolism 49, 1188-1196 http://dx.doi.org/10.1053/meta.2000.8620

Wilcox J. N., Blumenthal B. F. (1995): Thrombotic mechanisms in atherosclerosis: potential impact of soy proteins. J. Nutr. 125, S631-638

Xiao C. W., L'Abbe M. R., Gilani G. S., Cooke G. M., Curran I. H., Papademetriou S. A. (2004): Dietary soy protein isolate and isoflavones modulate hepatic thyroid hormone receptors in rats. J. Nutr. 134, 743-749

Yanovski J. A., Cutler G. B. Jr. (1994): Glucocorticoid action and the clinical features of Cushing's syndrome. Endocrinol. Metab. Clin. N. Am. 23, 487-509

Zhang R., Reisin E. (2000): Obesity-hypertension: the effects on cardiovascular and renal systems. Am. J. Hypertens. 13, $1308-1314$ http://dx.doi.org/10.1016/S0895-7061(00)01254-1

Zhang H. T., Wang Y., Deng X. L., Dong M. Q., Zhao L. M., Wang Y. W. (2010): Daidzein relaxes rat cerebral basilar artery via activation of large conductance $\mathrm{Ca}^{2+}$ activated $\mathrm{K}^{+}$channels in vascular smooth muscle cells. Eur. J. Pharmacol. 630, 100-106 http://dx.doi.org/10.1016/j.ejphar.2009.12.032

Zicha J., Kunes J., Devynck M. A. (1999): Abnormalities of membrane function and lipid metabolism in hypertension. Am. J. Hypertens. 12, 315-331

http://dx.doi.org/10.1016/S0895-7061(98)00178-2

Received: April 2, 2012

Final version accepted: May 28, 2012 